\title{
Bursa Bölgesinde Faaliyet Gösteren Üç Adet Broyler İşletmesinin Karbon Ayak İzinin Tahminlenmesi
}

\author{
Illker Kılıç* Büşra Yaylı Aydın Elekberov \\ Bursa Uludağ Üniversitesi, Ziraat Fakültesi, Biyosistem Mühendisliği Bölümü, Bursa
}

Geliş tarihi (Received): 09.11.2018 Kabul tarihi (Accepted): 10.12.2018

\begin{abstract}
Anahtar kelimeler:
Karbon ayak izi, küresel ısınma, sera gazı, broyler kümesi

*Sorumlu yazar

ikilic@uludag.edu.tr

Özet. Türkiye'de nüfusun artması, buna bağlı olarak hayvansal kaynaklı proteine ihtiyacın artış göstermesi, tarımsal arazilerin yok olması, ürün veriminde sürekli artış elde edilmek istenmesi gibi nedenlerle entansif işletmeler yaygınlık kazanmıştır. Birim alanda daha fazla üretim yapılan yoğun işletmecilik sistemlerinin bir sonucu olarak olumsuz çevresel etkileri artmakta ve gaz emisyonlarıla küresel ısınmaya katkı sağlamaktadır. Küresel ııınmaya sebep olan sera gazlarının başında metan $\left(\mathrm{CH}_{4}\right)$, karbondioksit $\left(\mathrm{CO}_{2}\right)$ ve diazot oksit $\left(\mathrm{N}_{2} \mathrm{O}\right)$ gelmektedir. Bir işletmenin küresel ısınmaya katkısının en önemli göstergelerinden birisi karbon ayak izidir. İşletmenin karbon ayak izi hesaplanmasıyla o işletmenin küresel ısınmaya olan katkısı da belirlenmiş olacaktır. Karbon ayak izinin hesaplanmasında kullanılan en yaygın yöntem Hükümetlerarası İklim Değişikliği Paneli (IPCC) tarafından geliştirilen Tier yaklaşımlarıdır. Tier yaklaşımı 1, 2 ve 3 olmak üzere üç çeşittir. Bu çalışmada; Bursa bölgesinde faaliyet gösteren üç farklı broyler kümesinin karbon ayak izi belirlenmesi amacıyla Tier 1 yöntemi kullanılarak küresel ısınmaya etkisinin ortaya konması amaçlanmıştır. Çalışma sonucunda, incelenen broyler kümeslerinde üretilen $1 \mathrm{~kg}$ tavuk eti başına karbon ayak izi broyler kümesi 1, 2 ve 3 için sırasıyla 2.2, 3.4 ve $3 \mathrm{~kg} \mathrm{CO}$ eşdeğerliği olarak bulunmuştur.
\end{abstract}

\section{Estimation of Carbon Footprint of Three Broiler Houses Operated in Bursa Region}

\section{Keywords:}

Carbon footprint, global warming, greenhouse gas, broiler farm

\begin{abstract}
Increasing the population in Turkey, accordingly, the increase in the need for animal-derived protein, destruction of agricultural lands, demand continous input of product yield for reasons such as intensive operation have gained widespread. As a consequence of intensive management system where more production is made in the unit area, negative enviromental impacts are increasing and contribute to global warming with gas emissions. Methane $\left(\mathrm{CH}_{4}\right)$, carbon dioxide $\left(\mathrm{CO}_{2}\right)$ and diazot oxide $\left(\mathrm{N}_{2} \mathrm{O}\right)$ are the main greenhouse gases that cause global warming. Carbon footprint is the measure of the damage caused by human activities to the environment in terms of the amount of greenhouse gases that are measured in units of carbon dioxide. The most common method used in calculating carbon footprint are Tier 1-2-3 approaches developed by the Intergovernmental Panel on Climate Change (IPCC). The aim of this study is to determine the effect of three different broiler farms in Bursa region on global warming by using Tier 1 method to determine the carbon footprint. At the end of the study, carbon footprint per $\mathrm{kg}$ of produced hen meat in monitored broiler houses 1,2 and 3 were calculated as $2.2,3.4$ ve $3 \mathrm{~kg} \mathrm{CO} 2$ equivalent, respectively.
\end{abstract}




\section{Giriş}

Dünya nüfusu sürekli olarak artmaktadır. Birleşmiş Milletler (BM) tarafından yapılan son tahminlere göre, dünya nüfusunun 2030 yılında 8.6 milyar, 2050 yılında 9.8 milyar ve 2100 yılında 11.2 milyara ulaşması beklenmektedir. Artan nüfusla birlikte gıdaya olan talep de artmaktadır. Dengeli beslenme için günlük alınması gereken besin ihtiyacının önemli bir kısmını hayvansal kaynaklı proteinler oluşturmaktadır. Yapılan bir çalışmaya göre ülkemizde tavuk etinin az yağlı, protein değerinin yüksek, vitamin ve mineraller açısından zengin olması, hazırlanmasının kolaylığı, çok çeşitli yemeklerde kullanılabilmesi ve fiyatlarının kırmızı ete kıyasla çok daha uygun olması gibi nedenler tavuk eti tüketimini artırmıştır (Dokuzlu ve ark., 2013). Artan nüfustaki bu istekleri karşılamak için birim alanda yoğun üretim yapılan broyler işletmeleri yaygınlık kazanmaya başlamıştır. Ancak hayvansal üretimde entansifleşmenin olumsuz bir sonucu olarak çevre üzerindeki baskılar ve küresel ısınmaya sebep olan sera gazları emisyonlarının etkileri artmıştır.

Küresel ısınma; çoğunlukla insan faaliyetlerinin sonucunda ortaya çıkan sera gazı emisyonlarının (başlıca karbondioksit, metan ve diazot oksit) dünya üzerinde sıcaklık artışına neden olmasıdır. Kyoto Protokolü'nde küresel ısınmaya neden olan sera gazları ve salınım kaynakları karbondioksit $\left(\mathrm{CO}_{2}\right)$, metan $\left(\mathrm{CH}_{4}\right)$, diazot oksit $\left(\mathrm{N}_{2} \mathrm{O}\right)$, hidroflorür karbonlar (HFCs), perfloro karbonlar (PFCs) ve sülfürhekza florid $\left(\mathrm{SF}_{6}\right)$ olarak belirtilmiştir.

Endüstriyel işletmelerin küresel ısınmaya olan etkilerini belirlemek amacıyla karbon ayak izi kavramı ortaya çıkmıştır. Karbon ayak izi; birim karbondioksit cinsinden ölçülen, üretilen sera gazı miktarı açısından insan faaliyetlerinin çevreye verdiği zararın ölçüsüdür (Çınar 2007; Kılıç ve Amet 2017). Diğer bir ifadeyle; kurum veya bireylerin ulaşım, ısınma, elektrik tüketimi gibi faaliyetlerden kaynaklanan toplam sera gazları salım miktarının karbondioksit cinsinden ifadesidir. Karbon ayak izi; birincil ayak izi ve ikincil ayak izi olmak üzere ikiye ayrılmaktadır. Birincil ayak izi; evsel enerji tüketimi ve ulaşım da dâhil olmakla birlikte fosil yakıtların yanmasından ortaya çıkan doğrudan $\mathrm{CO}_{2}$ emisyonlarının ölçüsüdür. İkincil ayak izi ise; kullandığımız ürünlerin tüm yaşam döngüsünden, bu ürünlerin imalatı ve en sonunda bozulmalarıla ilgili olan dolaylı $\mathrm{CO}_{2}$ emisyonlarının ölçüsüdür. $\mathrm{Bu}$ çalışmada ikincil karbon ayak izi incelenecektir. IPCC sera gazları emisyonlarının ölçülerinin hesaplanabilmesi için Tier 1-2-3 yöntemlerini geliştirmiş̧tir.
Food and Agriculture Organization of the United Nation (FAO)'a göre toplam sera gazının \%18'i tarımsal faaliyetler sonucunda açığa çıkmaktadır ve bu değerin \%14.5'i hayvancilık işletmelerinden kaynaklanmaktadır. Gerber et al. (2013), küresel ısınma potansiyelinin $\left(\mathrm{CO}_{2}\right.$ eşdeğerlik olarak) \%14.5'ini hayvansal üretim oluşturmakta olduğunu ve hayvancılık sektöründen kaynaklanan emisyonların \%8'inin ise kümes hayvancılığı ve büyükbaş hayvancılıktan kaynaklandığını belirtmişlerdir. Hayvancılık işletmeleri, $\mathrm{CH}_{4}$ ve $\mathrm{N}_{2} \mathrm{O}$ emisyonları açısından önemli üretici kaynaklardır. Hükümetlerarası İklim Değişikliği Paneli'nin 100 yıllık bir zaman sürecini göz önüne alarak $\mathrm{CO}_{2}$ eşdeğerliği cinsinden küresel Isınma potansiyellerinin $1 \mathrm{~kg} \mathrm{CH}_{4}$ gazının $25 \mathrm{~kg} \mathrm{CO}_{2}$ ve $1 \mathrm{~kg} \mathrm{~N} 2 \mathrm{O}$ gazının $298 \mathrm{~kg} \mathrm{CO} 2$ ile eşdeğer olduğunu belirtmiştir. $\mathrm{Bu}$ veriler $\mathrm{N}_{2} \mathrm{O}$ gazının atmosferde ısıyı absorbe etme kapasitesinin $\mathrm{CH}_{4}$ gazından daha yüksek olduğunu göstermektedir. Broyler kümeslerinden kaynaklanan gaz emisyonlarını $\mathrm{N}_{2} \mathrm{O}, \mathrm{NH}_{3}, \mathrm{CH}_{4}$ ve $\mathrm{CO}_{2}$ oluşturmaktadır.

Bu çalışmanın amacl; Bursa ilinde faaliyet gösteren üç adet broyler işletmesinde barınak sınıları içerisinde ortaya çıkan sera gazlarının emisyonlarının ölçülerek karbon ayak izinin tahminlenmesidir.

\section{MATERYAL VE METOT}

$\mathrm{Bu}$ çalışmanın materyalini karbon ayak izinin tahminlemesi amacıyla Bursa'da faaliyet gösteren üç adet broyler işletmesi oluşturmaktadır.

Broyler sektöründe çevresel etkilerde önemli rol oynayan konular şunlardır: üretim performansları (besleme, yem dönüşüm oranı, canlı ağırlığı, ölüm oranı), gübre yönetimi, enerji sarfiyatı ve birim alandaki yoğunluktur (Bengtsson and Seddon 2013; Da Silva et al., 2014; Leinonen et al., 2014). Karbon ayak izi tahminlenirken $\mathrm{CO}_{2}, \quad \mathrm{~N}_{2} \mathrm{O}, \mathrm{CH}_{4}$ emisyonları incelenmektedir ve $\mathrm{N}_{2} \mathrm{O}$ ve $\mathrm{CH}_{4}$ gazlarının $\mathrm{CO}_{2}$ cinsinden eşdeğerlikleri belirlenmektedir. Dunkley et al. (2015)'nın yaptıkları bir çalışmada, hayvancılık işletmelerindeki emisyonları mekanik ve mekanik olmayan emisyonlar şeklinde belirtmişlerdir.

Yapılan çalışmada barınaklardan oluşan emisyonlar; üretime yardımcı sistemlerden oluşan emisyonlar ve üretimden olan emisyonlar olarak incelenmiştir.

\section{Üretime Yardımcı Sistemlerden Oluşan Emisyonlar}

Broyler işletmelerindeki emisyonların çoğunluğunu üretime yardımcı sistemlerden oluşan emisyonlar 
oluşturmaktadır. Çalışmada incelenen broyler işletmelerinde üretime yardımcı sistemlerden olan emisyon kaynaklarını; havalandırma, aydınlatma ve elektrik tüketimi ile ısıtma için kullanılan yakıtlardan kaynaklanan emisyonlar oluşturmaktadır.

Barınak ortamında hayvanlar için temiz iç ortam havasının oluşması havalandırmayla mümkün olmaktadır. Havalandırma yapmak tavukların sağlıklı kalabilmesi ve yemlemede randıman açısından önemlidir. Çalışmamı kapsamındaki broyler kümeslerinde havalandırma mekanik yolla sağlanmaktadır. Kümeslerde aydınlatma tavukların fizyolojik davranışları ve verimlilikleri açısından önemlidir. Genel olarak gündüzleri pencere ile akşamları ise lambalar ile aydınlatma yapılmaktadır. İncelenen işletmelerdeki aydınlatma planına göre 12 saat aydınlatma yapılmaktadır. Karbon ayak izinin tahminlenmesi için elektrik emisyon faktörü $0.40 \mathrm{~kg}$ $\mathrm{CO}_{2}$ eşdeğerlik kW h${ }^{-1}$ (Jacobsen et al., 2014) olarak alınmıştır (Çizelge 1).

Çizelge 1. Karbon ayak izinde kullanılan elektrik ve yakıt için emisyon faktörleri (Jacobsen et al., 2014).

Table 1. Electric and fuel emission factors used in carbon footprint.

\begin{tabular}{lcc}
\hline İsim & Katsayı & Birim \\
\hline Elektrik & 0.40 & $\mathrm{~kg} \mathrm{CO}_{2}$ eşdeğerliği $\mathrm{kWh}^{-1}$ \\
Motorin & 2.66 & $\mathrm{~kg} \mathrm{CO}_{2}$ eşdeğerliği kg-1 \\
Kömür & 2.86 & $\mathrm{~kg} \mathrm{CO}_{2}$ eşdeğerliği kg \\
\hline
\end{tabular}

Tavuklar sıcaklığa karşı hassas hayvanlardır ve kümes iç ortam ısısı önemlidir. Barınağın ısıtılmasında yakıt olarak kömür kullanılmaktadır. Ayrıca ölmüş hayvanların imhası için kullanılan yakma fırınlarında da kömür kullanılmaktadır. Yakma işlemi sonucunda salınan en önemli gazlar $\mathrm{CO}_{2}, \mathrm{SO}_{2}$ ve $\mathrm{CO}^{\prime}$ dir. Kömürün yakılmasıyla açığa çıkan emisyon faktörü $2.86 \mathrm{~kg} \mathrm{CO}$ eşdeğerlik $\mathrm{kg}^{-1}$ (ElA 1994) ve dizel yakıt emisyon faktörü ise $2.66 \mathrm{~kg} \mathrm{CO}_{2}$ eşdeğerlik kg-1 (Jacobsen et al., 2014) olarak alınmıştır (Çizelge 1).

Barınak ortamında yem dağıtım gibi çeşitli amaçlarla kullanılan çiftlik ekipmanları için de yararlanılan yakıtlardan emisyonlar ortaya çıkmaktadır.

\section{Üretimden ya da Kümeslerden olan Emisyonlar}

Incelenen broyler işletmelerinden açığa çıkan gübre ve altlık materyalinden oluşan emisyonlar bu gruba girmektedir. Tavuklarda ruminant sistem yoktur, geviş getirmezler. Basit mideye sahiptirler ve çok az mikrobiyal fermantasyon gerçekleştirirler. Organik atıklardan temel olarak (gübre ve altlık malzeme atıkları) $\mathrm{NH}_{3}, \mathrm{~N}_{2} \mathrm{O}$ ve $\mathrm{CH}_{4}$ gazı emisyonları ortaya çıkmaktadır. Yapılan bir çalışmada, altık materyal ve gübrenin karışımından (taşıma, depolama ve uygulama dâhil) $\mathrm{NH}_{3}, \quad \mathrm{~N} 2 \mathrm{O}, \mathrm{CH}_{4}, \mathrm{NO}_{3}^{-}$ve $\mathrm{PO}_{3}^{-3}$ emisyonlarının açığa çıktığını belirtilmiştir (GonzálezGarcia et al., 2014).

Çalışmada sera gazı konsantrasyon değerleri kış ve yaz mevsimleri boyunca 24 saat sürekli olarak üç adet broyler işletmesinde çoklu gaz analizörü (Multi RAE Lite, Honeywell, USA) ile ölçülmüştür. Ölçülen sera gazları için aşağıda verilen eşitlik (Eşitlik 1) yardımıyla emisyon değerleri hesaplanmıştır (Hinze and Linke 1998). $\mathrm{N}_{2} \mathrm{O}$ için emisyon değerleri literatürde yapılan çalışmalardan alınmıştır (Burns et al., 2008).

$E=(C e-C i) \cdot Q$

Eşitlikte;

$\mathrm{E}=$ Kümesten olan emisyon miktarı, $\left(\mathrm{g} \mathrm{h}^{-1}\right)$

$\mathrm{Ce}=$ Kirletici gazların barınak içerisindeki konsantrasyonu, $\left(\mathrm{g} \mathrm{m}^{-3}\right)$

$\mathrm{Ci}=$ Kirletici gazların giriş konsantrasyonu, $\left(\mathrm{g} \mathrm{m}^{-3}\right)$ $\mathrm{Q}=$ Barınakta uygulanan havalandırma miktarı, $\left(\mathrm{m}^{3} \mathrm{~h}^{-1}\right)$

Üretimden olan emisyonlar için $\mathrm{CH}_{4}$ ve $\mathrm{N}_{2} \mathrm{O}$ emisyonlarının $\mathrm{CO}_{2}$ eşdeğerlikleri IPCC (2006)'den alınmıştır (Çizelge 2).

Çizelge 2. $\mathrm{CH}_{4}$ ve $\mathrm{N}_{2} \mathrm{O}$ emisyon faktör değerleri.

Table 2. $\mathrm{CH}_{4}$ and $\mathrm{N}_{2} \mathrm{O}$ emission factor values.

\begin{tabular}{ccc}
\hline Parametre & $\begin{array}{c}\text { Emisyon Faktörü } \\
\text { kg CO}\end{array}$ & eşdeğerliği \\
\hline $\mathrm{CH}_{4}$ & 25 & IPCC (2006) \\
$\mathrm{N}_{2} \mathrm{O}$ & 298 & IPCC (2006) \\
\hline
\end{tabular}

\section{Çalışmanın Sistem Sınırları}

Bu çalışmanın sistem sınırlarını, ham maddenin işletmeye girmesinden ürünün çiftlik kapısından çıkmasına kadar ki benzin ve ilaç tüketimi dışındaki tüm süreçleri içermektedir. Çalışmada dikkate alınan tüm girdi ve çıktılar Şekil 1'de verilmiştir. İşletmedeki elektrik kullanımı, çiftlik yakıtı, yem takviyeleri girdileri oluştururken; tavuk eti, diğer yan ürünler ve atık gübre çıktıları oluşturmaktadır.

\section{Fonksiyonel Birim}

Çalışmada karbon ayak izi belirlenen fonksiyonel birim başına hesaplanmıştır. Buna göre broyler et üretimi konusunda yapılan çalışmalar incelendiğinde (González-Garcia et al., 2014), fonksiyonel birim olarak $1 \mathrm{~kg}$ tavuk eti veya marketlerde satışa sunulan $1.2 \mathrm{~kg}$ ağırlığında 1 paket tavuk eti olarak alındığı görülmüştür. Bu noktadan hareketle çalışmada, fonksiyonel birim olarak $1 \mathrm{~kg}$ çiğ tavuk eti göz önüne alınmıştır. 


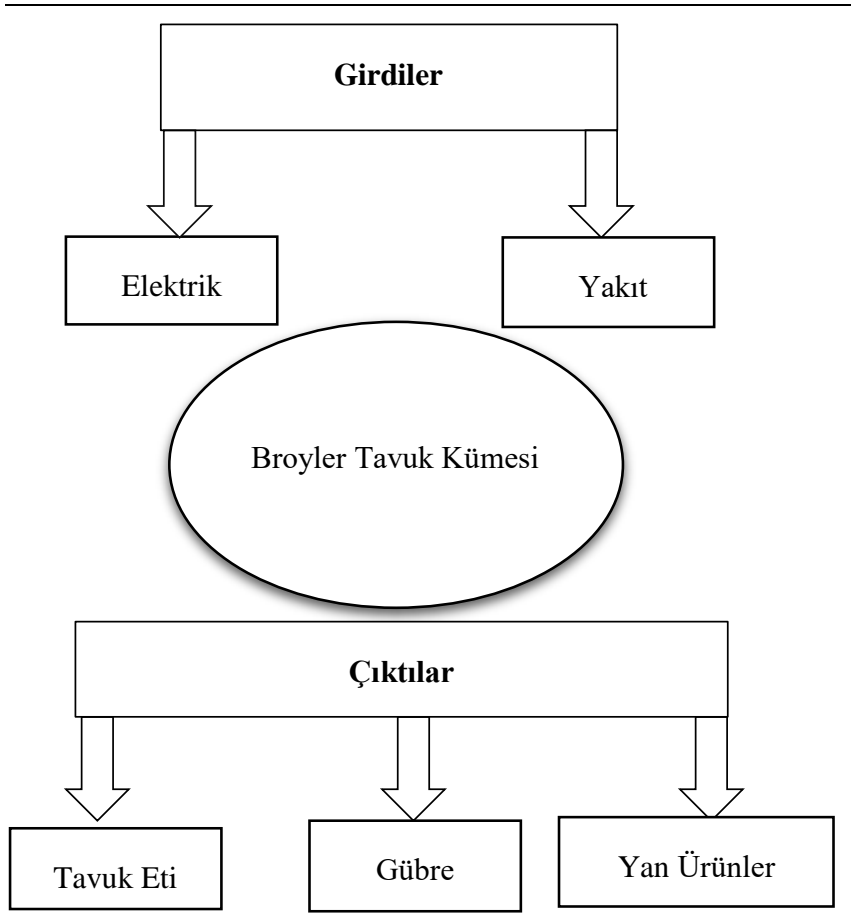

\section{BULGULAR VE TARTIŞMA}

Bu çalışmada; Bursa ilinde faaliyet gösteren üç adet broyler işletmesinde barınak sınırları içerisinde ortaya çıkan sera gazlarının emisyonlarının ölçülerek karbon ayak izinin tahminlenmesi amaçlanmıştır.

Araştırma, hayvansal üretimin yoğun olarak yapıldığı Bursa ilinin Nilüfer ilçesine bağlı Akçalar ve Görükle Mahalleleri (Broyler Kümesi (BK) 1 ve 3) ile Karacabey ilçesine bağlı Gölkıyı Köyü (Broyler Kümesi 2)'nde bulunan kümeslerde yürütülmüştür. İncelenen kümeslere ilişkin yapısal ve boyutsal özellikler Çizelge 3 ve $4^{\prime}$ de verilmiştir.

BK1'de mekanik havalandırma sisteminde $150 \mathrm{~cm}$ çapında 4 adet fan kullanırken, BK2'de $120 \mathrm{~cm}$ çapında 5 adet ve BK3'de ise bir adet $200 \mathrm{~cm}$ çapındaki havalandırma fanı kullanılmaktadır. Yaz döneminde BK1 ve BK3'te iç ortam sıcaklığını azaltmak için havalandırma dışında soğutma pedleri de kullanılmaktadır.

Şekil 1. Çalışmanın sistem sınırları.

Figure 1. The system boundaries of this study.

Çizelge 3. İncelenen işletmelerin yapısal özellikleri.

Table 3. Structural characteristics of the monitored operations.

\begin{tabular}{lccccccc}
\hline Kümesler & $\begin{array}{c}\text { İşletme } \\
\text { yeri }\end{array}$ & $\begin{array}{c}\text { Yetiştiricilik } \\
\text { sistemi }\end{array}$ & Kapasite & $\begin{array}{c}\text { Yerleşim sıklığı } \\
\text { tavuk } \mathbf{~ m}^{-2}\end{array}$ & $\begin{array}{c}\text { Havalandırma } \\
\text { sistemi }\end{array}$ & $\begin{array}{c}\text { Gübre } \\
\text { temizleme }\end{array}$ & $\begin{array}{c}\text { Bina } \\
\text { yönü }\end{array}$ \\
\hline BK1 & Akçalar & Altlık Sistem & 10000 & 33 & Mekanik & Altlık+Gübre & Kuzey-Doğu \\
BK2 & Gölkıyı & Altlık Sistem & 12000 & 10 & Mekanik+Doğal & Altlık+Gübre & Kuzey-Doğu \\
BK3 & Görükle & Altlık Sistem & 24000 & 33 & Mekanik & Altlık+Gübre & Doğu-Batı \\
\hline
\end{tabular}

Çizelge 4. İncelenen kümeslerin boyutsal özellikleri.

Table 4. Dimensional properties of the examined shelter.

\begin{tabular}{lccc}
\hline Kümesler & En $(\mathbf{m})$ & Boy $(\mathbf{m})$ & Duvar Yüksekliği $(\mathbf{m})$ \\
\hline BK1 & 8.6 & 39 & 2.2 \\
BK2 & 12.5 & 100 & 2.9 \\
BK3 & 14.4 & 27.7 & 2.7 \\
\hline
\end{tabular}

Incelenen broyler işletmeleri ile ilgili genel bilgiler Çizelge 5 'de verilmiştir. Karbon ayak izi için önemli olan işletme özellikleri emisyonların miktarını önemli düzeyde etkilemektedir.

Çizelge 5. İncelenen kümeslerin üretim özellikleri. Table 5. Productional characteristics of the shelter examined.

\begin{tabular}{lc}
\hline Parametre & Miktar \\
\hline Yem tüketimi (kg) & 4.4 \\
Yetiştirme süresi (gün) & 40 \\
Ortalama kesim ağırlığı (kg) & 2 \\
\hline Tavuk Eti Üretimi (kg) & \\
BK 1 & 20000 \\
BK 2 & 24000 \\
BK 3 & 48000 \\
\hline
\end{tabular}

Buna göre üretilen $1 \mathrm{~kg}$ tavuk eti başına gereksinim duyulan girdi miktarları Çizelge 6 'da verilmiştir.

Çizelge 6. Üretilen $1 \mathrm{~kg}$ tavuk eti için gereksinim duyulan üretim girdileri.

Table 6. Required production inputs per $\mathrm{kg}$ of chicken meat.

\begin{tabular}{ll}
\hline Parametre & Miktar \\
\hline Yem tüketimi $(\mathbf{k g})$ & \\
BK1 & 0.95 \\
BK2 & 0.95 \\
BK3 & 1.05 \\
\hline Kömür kullanımı (kg) & \\
BK1 & 0.22 \\
BK2 & 0.25 \\
BK3 & 0.20 \\
\hline
\end{tabular}


Çalışmada incelenen kümeslerde, $1 \mathrm{~kg}$ tavuk eti başına ortalama $1.76 \mathrm{~kg}$ gübre üretilmiştir. Işletmelerde üretilen gübre miktarı üretilen tavuk eti miktarına oranlanarak bu değer hesaplanmıştır. Incelenen işletmelerin gübrelerini çevrede bitkisel üretimde organik gübre olarak kullanmak üzere diğer çiftçilere ücretsiz olarak verdikleri belirlenmiştir. Ancak gübrelerin işletme içerisinde uygun koşullarda depolanmadığı da gözlemlenmiştir.

Çalışmada incelenen kümeslerden $1 \mathrm{~kg}$ tavuk eti başına açığa çıkan $\mathrm{N}_{2} \mathrm{O}, \mathrm{CH}_{4}$ ve $\mathrm{CO}_{2}$ gaz emisyon miktarları Çizelge 7'de verilmiştir.

Çizelge 7. Üretilen $1 \mathrm{~kg}$ tavuk eti başına açığa çıkan $\mathrm{N}_{2} \mathrm{O}$, $\mathrm{CH}_{4}$ ve $\mathrm{CO}_{2}$ gaz emisyonları.

Table 7. $\mathrm{N}_{2} \mathrm{O}, \mathrm{CH}_{4}$ and $\mathrm{CO}_{2}$ gas emissions per $\mathrm{kg}$ chicken meat produced.

\begin{tabular}{lcccc}
\hline Kaynak & Kümes & $\mathbf{N}_{\mathbf{2}} \mathbf{O}$ & $\mathbf{C H}_{\mathbf{4}}$ & $\mathbf{C O}_{\mathbf{2}}$ \\
\hline Kümes & BK1 & 0.0131 & 0.000004 & 0.960 \\
(kg/40 gün.1 kg & BK2 & 0.0131 & 0.000008 & 1.069 \\
tavuk eti) & BK3 & 0.0131 & 0.000001 & 0.420 \\
\hline Gübreden & BK1 & 0.0557 & 0.000019 & 4.094 \\
(kg/40 gün.1 kg & BK2 & 0.0557 & 0.000034 & 4.558 \\
tavuk eti) & BK3 & 0.0557 & 0.000004 & 1.789 \\
\hline
\end{tabular}

Üretilen kirletici gaz emisyonlarından $\mathrm{CH}_{4}$ ve $\mathrm{CO}_{2}$ barınak içerisinde yapılan ölçümler sonucunda bulunurken $\mathrm{N}_{2} \mathrm{O}$ değerleri Burns et al. (2008)'ten alınmıştır. Bu çalışmada, incelenen broyler kümesi ile benzer özellikler gösteren bir broyler kümesinde yapılan ölçümler sonucunda $\mathrm{N}_{2} \mathrm{O}$ emisyonunu tavuk başına $1.72 \mathrm{gr}$ olarak ölçmüşlerdir. Bu değer kullanılarak çalışmamızda incelenen broyler kümeslerinden kaynaklanan $\mathrm{N}_{2} \mathrm{O}$ emisyonları hesaplanmıştır. Barınak iç ortamında ölçülen $\mathrm{CH}_{4}$ konsantrasyonunun yaklaşık \%81'i altık ile karışmış olan gübre sonucunda oluşmaktadır. Kalan \%19'luk kısım ise kümesten iç ortamından kaynaklanmaktadır (Cederberg et al., 2009).

Çizelge 8' de incelenen broyler kümeslerinin karbon ayak izini oluşturan farklı parametreler verilmiştir. Çalışma sınırları içerisinde değerlendirilen her bir parametrenin karbon ayak izinden hareketle işletmenin toplam karbon ayak izine ulaşılmıştır.

Cesari et al. (2017), İtalya'da faaliyet gösteren broyler işletmelerinin karbon ayak izini belirledikleri çalışmalarında, 1.6 kg'lık ortalama canlı ağırlığa sahip olan tavuklar için küresel ısınma potansiyelini $1 \mathrm{~kg}$ tavuk eti başına $3.03 \quad \mathrm{kgCO}_{2}$ eşdeğerliği olarak bulmuşlardır. Bu değer, çalışmamızda bulduğumuz değerler ile uyum içerisindedir. Gonzalez-Garcia et al. (2014), Portekiz et tavukçuluğunun yaşam döngüsü değerlendirmesini yaptıkları çalışmalarında ise 1.2 kg'lık ortalama canlı ağırlığa sahip olan tavuklar için küresel ısınma potansiyelini $2.7 \mathrm{~kg} \mathrm{CO}$ eşdeğerliği olarak hesaplamışlardır. Bu çalışmada incelenen kümesteki tavukların canlı ağırlıklarının çalışmamızda incelenen tavuklara göre daha az olması nedeniyle yem tüketimlerinin azalması ve dolayısıyla üretilen birim tavuk eti başına üretilen $\mathrm{CO}_{2}$ miktarını azaltmıştır. Ancak, çalışmamızda hesaplanan ortalama karbon ayak izi değeri ile benzerlik göstermektedir.

Çizelge 8. Incelenen broyler kümeslerinin karbon ayak izi. Table 8. Carbon footprint of the monitored broiler houses.

\begin{tabular}{|c|c|c|c|}
\hline \multirow[t]{2}{*}{ Kaynak } & \multirow[t]{2}{*}{ Kümes } & \multicolumn{2}{|c|}{ Karbon Ayak İzi ( 1 kg tavuk eti için) } \\
\hline & & kg CO 2 eşdeğerliği & $\%$ \\
\hline & BK 1 & 0.3 & 13.3 \\
\hline \multirow[t]{3}{*}{ Kümes } & BK 2 & 0.5 & 14.9 \\
\hline & BK 3 & 0.4 & 15.1 \\
\hline & BK 1 & 1.3 & 56.9 \\
\hline \multirow[t]{3}{*}{ Gübre } & BK 2 & 2.2 & 63.6 \\
\hline & BK 3 & 1.9 & 64.5 \\
\hline & BK 1 & 0.0 & 1.2 \\
\hline \multirow[t]{3}{*}{ Elektrik } & BK 2 & 0.0 & 0.7 \\
\hline & BK 3 & 0.0 & 0.9 \\
\hline & BK 1 & 0.6 & 28.5 \\
\hline \multirow[t]{3}{*}{ Kömür } & BK 2 & 0.7 & 20.8 \\
\hline & BK 3 & 0.6 & 19.5 \\
\hline & BK 1 & 2.2 & \\
\hline \multirow[t]{2}{*}{ Toplam } & BK 2 & 3.4 & 100 \\
\hline & BK 3 & 3.0 & \\
\hline
\end{tabular}

Çalışmada incelenen kümeslerde karbon ayak izinin mevsimlere göre değişimi Çizelge 9'da verilmiştir. Çizelgeye göre yaz mevsiminde gerçekleşen karbon ayak izi değerleri kış mevsimine göre daha düşük seyretmiştir.

Çizelge 9. Karbon ayak izinin mevsimlere göre değişimi. Table 9. The variations in carbon footprint of broiler houses in different season.

\begin{tabular}{|c|c|c|c|}
\hline Kaynak & Kümes & Kış & Yaz \\
\hline \multirow{3}{*}{$\begin{array}{l}\text { Kümes } \\
\text { kg CO} 2 \text { eşdeğerliği }\end{array}$} & BK 1 & 0.07 & 0.23 \\
\hline & BK 2 & 0.26 & 0.25 \\
\hline & BK 3 & 0.24 & 0.21 \\
\hline \multirow{3}{*}{$\begin{array}{l}\text { Gübre } \\
\text { kg CO} 2 \text { eşdeğerliği }\end{array}$} & BK 1 & 0.29 & 0.98 \\
\hline & BK 2 & 1.12 & 1.06 \\
\hline & BK 3 & 1.02 & 0.89 \\
\hline \multirow{3}{*}{$\begin{array}{l}\text { Elektrik } \\
\text { kg CO} \mathrm{CO}_{2} \text { eşdeğerliği }\end{array}$} & BK 1 & 0.02 & 0.01 \\
\hline & BK 2 & 0.01 & 0.01 \\
\hline & BK 3 & 0.02 & 0.01 \\
\hline \multirow{3}{*}{$\begin{array}{l}\text { Kömür } \\
\text { kg CO} 2 \text { eşdeğerliği }\end{array}$} & BK 1 & 0.64 & - \\
\hline & BK 2 & 0.72 & - \\
\hline & BK 3 & 0.58 & - \\
\hline \multirow{3}{*}{$\begin{array}{l}\text { Toplam } \\
\text { kg CO} 2 \text { eşdeğerliği }\end{array}$} & BK 1 & 1.0 & 1.2 \\
\hline & BK 2 & 2.1 & 1.3 \\
\hline & BK 3 & 1.8 & 1.2 \\
\hline
\end{tabular}

Şekil 2'ye göre broyler işletmelerinin karbon ayak izinin önemli bir bölümü gübreden kaynaklanmaktadır. Buna karşın en az katkıyı tüketilen elektriğin neden olduğu $\mathrm{CO}_{2}$ eşdeğerliğinde sera gazı emisyonları sağlamaktadır. 

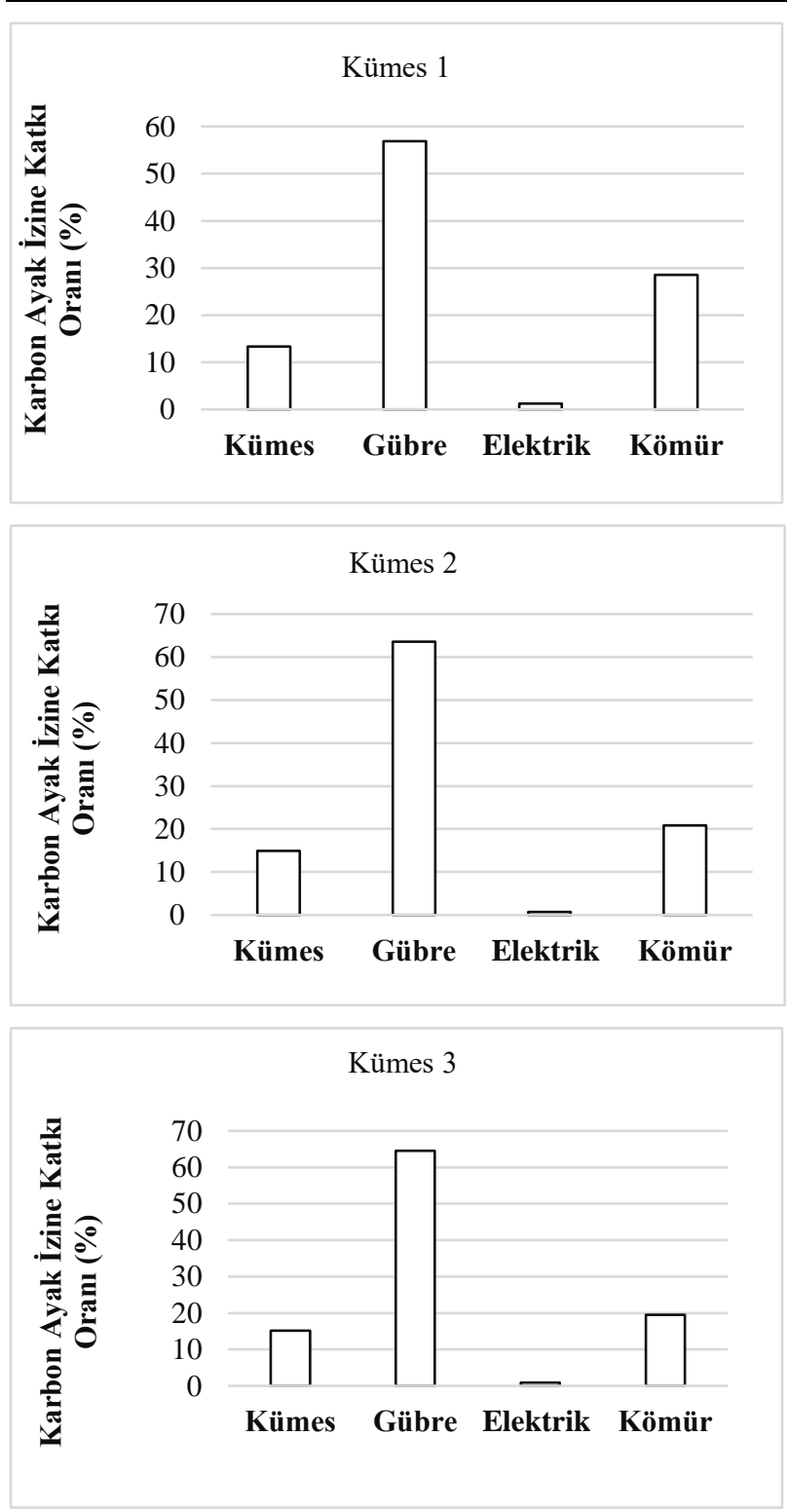

Şekil 2. Parametrelerin karbon ayak izine katkıları. Figure 2. Contributions of parameters to carbon footprint.

\section{SONUÇ}

Çalışma sonuçlarına göre incelenen broyler işletmelerinin $1 \mathrm{~kg}$ tavuk eti üretimine karşılık BK1, BK2 ve BK3 için sırasıyla $2.2,3.4$ ve $3.0 \mathrm{~kg} \mathrm{CO}$ ürettiği belirlenmiştir. Çalışmada Bursa bölgesi koşullarında yetiştiricilik yapan broyler kümeslerinin $1 \mathrm{~kg}$ tavuk eti üretimi için ortalama $2.9 \mathrm{~kg} \quad \mathrm{CO}_{2}$ ürettikleri hesaplanmıştır.

İşletmenin girdi ve çıktılarının karbon ayak izi üzerindeki etkileri açısından değerlendirildiğinde en büyük kısmını gübreden kaynaklanan emisyonlardan oluştuğu ve işletmede kullanılan elektriğin ise en küçük paya sahip olduğu belirlenmiştir. Bu nedenle Bursa bölgesinde faaliyet gösteren broyler işletmelerinin karbon ayak izinin azaltılması için gübreden kaynaklanan emisyonlar üzerinde durulması gerekmektedir. Özellikle gübrenin uygun koşullarda depolanması ve gaz emisyonlarının azaltılmasına yönelik işletmelere özgü en uygun azaltma stratejilerinin uygulanması gerekmektedir.

Bu kapsamda, gübreden kaynaklanan emisyonları azaltacak, yem rasyonunda değişiklik, yeme ilave maddeler eklenmesi, iyi planlanmış gübre işletim sistemleri gibi çeşitli stratejilerin uygulanması önerilmektedir.

\section{KAYNAKLAR}

Bengtsson J and Seddon J., 2013. Cradle to retailer or quick service restaurant gate life cycle assessment of chicken products in Australia. Journal of Cleaner Production, 41: 291-300.

Burns RT., Li H., Xin H., Gates RS., Overhults DG., Earnest J and Moody L., 2008. Greenhouse Gas (GHG) Emissions from Broiler Houses in the Southeastern United States. American Society of Agricultural and Biological Engineers Annual International Meeting, June 29-July 2, USA.

Cederberg C., Sonesson U., Henriksson M., Sund V and Davis J., 2009. Greenhouse Gas Emissions from Swedish Production of Meat, Milk and Eggs 1990 and 2005. SIK Report No 794, SIK-the Swedish Institute for Food and Biotechnology, Gothenburg.

Cesari V., Zucali M., Sandrucci A., Tamburuni A., Bava L and Toschi I., 2017. Environmental impact assessment of an Italian vertically integrated broiler system through a Life Cycle approach. Journal of Cleaner Production, 143: 904 911.

Çınar E., 2007. İneklerin ekolojik ayak izi raporu. Animal Science Journal, 2013(Rum 38): 210-218.

Da Silva VP., Van der Werf HMG., Soares SR and Corson MS., 2014. Environmental impacts of French and Brazilian broiler chicken production scenarios: an LCA approach. Journal of Environmental Management, 133: 222-231.

Dokuzlu S., Barış O., Hecer C ve Güldaş M., 2013. Türkiye'de tavuk eti tüketim alışkanlıkları ve marka tercihleri. Uludağ Üniversitesi Ziraat Fakültesi Dergisi, 27(2):83-92.

Dunkley CS., Fairchild BD., Ritz CW., Kiepper BH and Lacy MP., 2015. Carbon footprint of poultry production farms in South Georgia: A case study. Poultry Science Association, 24: 73-79.

EIA 1994. Carbon Dioxide Emission Factors for Coal. https://www.eia.gov/coal/production/quarterly/co2_arti cle/co2.html. [Erişim: 29 Ağustos 2018].

González-García S., Gomez-Fernández Z., Dias AC., Feijoo G., Moreira MT and Arroja L., 2014. Life cycle assessment of broiler chicken production: A Portuguese case study. Journal of Cleaner Production, 74: 125-134.

Gerber PJ., Steinfeld H., Henderson B., Mottet A., Opio C., Dijkman J., Falcucci A and Tempio G., 2013. Tackling Climate Change through Livestock - A Global 
Kılıç ve ark., Bursa Bölgesinde Faaliyet Gösteren Üç Adet Broyler İşletmesinin Karbon Ayak İzinin Tahminlenmesi

Assessment of Emissions and Mitigation Opportunities. Food and Agriculture Organization of the United Nations (FAO), Rome.

Hinz T and Linke S., 1998. A comprehensive experimental study of aerial pollutants in and emissions from livestock buildings Part 2: Methods. Journal of Agricultural Engineering Research, 70: 111-118.

IPCC 2006. Guidelines for national Greenhouse Gas Inventories. https://www.ipcc-nggip.iges.or.jp/public/ 2006gl/. [Erişim: 26 Ağustos 2018].

Jacobsen R., Vandermeulen V., Vanhuylenbroeck $G$ and Gellynck X., 2014. A life cycle assessment application: the carbon footprint of beef in Flanders (Belgium).
Assessment of Carbon Footprint in Different Industrial Sectors, Springer Science+Business Media, 24(1): 73-79.

Kılıç İ ve Amet B., 2017. Bir süt sığırı işletmesinin karbon ayak izinin tahminlenmesi: Bursa örneği. Gaiosmanpaşa Üniversitesi Ziraat Fakültesi Dergisi, 34(Ek Sayı): 134-142.

Leinonen I., Williams AG and Kyriazakis I., 2014. The effects of welfare-enhancing system changes on the environmental impacts of broiler and egg production. Poultry Science, 93: 256-266.

United Nations 1998. Kyoto Protocol to the United Nations Framework Convention on Climate Change. https://unfccc.int/kyoto-protocol-html-version. [Erişim: 7 Ağustos 2018]. 